\title{
Analysis of thermal parameters of heat storages for use in vehicles with combustion engines
}

The propulsion system of a vehicle using an internal combustion engine generates a significant amount of waste heat during operation, which is almost entirely discharged into the environment without any useful effect. One of the ways of using waste heat is storing it, and then using, for example, when starting the engine in winter conditions. The application of the indicated solution, in particular for the combat vehicle will allow to reduce the effects of cold start and will shorten the time of preparing such a vehicle for combat operations. The article presents: types of heat accumulators that could be used in a military vehicle, the results of preliminary tests carried out on the test stand and the impact of an additional heat source on the time of heating the internal combustion engine and on emission of exhaust gas components.

Key words: thermal energy storage, heat storage, waste heat energy, engine's heat balance, PCM

\section{Introduction}

The combat vehicle is designed to work in specific conditions of battlefield. An important feature that should be possessed is the ability to quickly and easily integrate into activities and regardless of the climatic conditions, especially low temperatures or high humidity [1]. An important feature of modern vehicles is the possibility of thermal camouflage, which would make it impossible or difficult to detect and identify by infrared devices of enemy [2]. The use of a heat storage in the military vehicles can significantly reduce the time of vehicle preparation for battlefield operations, as well serve as a protection system. For example, if the radiator was damaged, it could allow the drive unit to be protected from overheating [1] and reduce thermal image of vehicle in infrared by reduction of the exhaust gases' temperature [2]. In other words heat storage layout is an interesting solution to use in combat vehicles, which can improve the heat management of such vehicles $[1,2]$.

\section{Heat storage systems}

Literature studies confirm that the subject of heat storage is still the subject of interest among research centres. Often, these solutions are dedicated to specific purposes, therefore their construction must meet a number of specific requirements. We can distinguish three basic methods of thermal energy storage [7]:

1. Sensible heat storage

2. Latent heat storage

3. Chemical transformation heat storage

The first method is the simplest, it relies on heating the heat storage material using its specific heat capacity [4]. It can be, for example, a liquid or a solid. Water, oils and liquid waxes are often used from liquids [7]. In mobile applications, it is usually a coolant of the engine.

Table 1 contains some examples of material used in sensible heat storages.

Second - latent heat storage - use of phase change energy is based on the use of a material that in the temperature range prevailing within the heat exchange system (combustion engine together with auxiliary systems - environment) can occur in at least two physical states, in solid and liquid. During the change phase (solid-liquid or liquidsolid), the heat associated with the phase is stored or released $[3,7]$.

Table 1. Sensible heat storage materials and their thermal properties in $20^{\circ} \mathrm{C}[3]$

\begin{tabular}{|l|c|c|c|c|c|}
\hline No. & Material & $\begin{array}{c}\text { Thermal } \\
\text { capacity } \\
{[\mathrm{kJ} / \mathrm{kg} \mathrm{K}]}\end{array}$ & $\begin{array}{c}\text { Thermal } \\
\text { conductivity } \\
{[\mathrm{W} / \mathrm{m} \mathrm{K}]}\end{array}$ & $\begin{array}{c}\text { Density } \\
{\left[\mathrm{kg} / \mathrm{m}^{3}\right]}\end{array}$ & $\begin{array}{c}\text { Energy } \\
\text { density } \\
{\left[\mathrm{kJ} / \mathrm{m}^{3}\right]}\end{array}$ \\
\hline 1 & Aluminium & 0.945 & 238.4 & 2700 & 2551.50 \\
\hline 2 & Copper & 0.419 & 372 & 8300 & 3477.70 \\
\hline 3 & Graphite & 0.609 & 155 & 2200 & 13339.80 \\
\hline 4 & Water & 4.183 & 0.609 & 998.3 & 4175.88 \\
\hline 5 & Sandstone & 0.710 & 1.8 & 2200 & 1562 \\
\hline
\end{tabular}

Table 2. Phase change materials and their thermal properties [3]

\begin{tabular}{|c|c|c|c|c|c|}
\hline No. & $\begin{array}{c}\text { Phase Change } \\
\text { Material } \\
(\mathrm{PCM})\end{array}$ & Type & $\begin{array}{c}\text { Melting } \\
\text { point } \\
{\left[{ }^{\circ} \mathrm{C}\right]}\end{array}$ & $\begin{array}{c}\text { Heat of } \\
\text { fusion } \\
{[\mathrm{kJ} / \mathrm{kg}]}\end{array}$ & $\begin{array}{c}\text { Thermal } \\
\text { conductivity } \\
{[\mathrm{W} / \mathrm{m} \mathrm{K}]}\end{array}$ \\
\hline 1 & Polyglycol E600 & Organic & 22 & 127.2 & 0.189 \\
\hline 2 & Butyl stearate & Organic & 19 & 140 & 0.21 \\
\hline 3 & Palmitic acid & Organic & 57.8 & 185.4 & 0.162 \\
\hline 4 & $\mathrm{Capric}$ acid & Organic & 32 & 152.7 & 0.153 \\
\hline 5 & $\mathrm{KNO}_{3} / \mathrm{NaNO}_{3}$ & Inorganic & 220 & 100.7 & 0.56 \\
\hline 6 & $\mathrm{CaCl}_{2} \cdot 6 \mathrm{H}_{2} \mathrm{O}$ & $\begin{array}{c}\text { Inorganic } \\
\text { hydrates }\end{array}$ & 29 & 187 & 0.53 \\
\hline 7 & $\begin{array}{c}\mathrm{LiNO}_{3} / \mathrm{KNO}_{3} / \mathrm{NaNO}_{3} \\
8\end{array}$ & $\begin{array}{c}\text { Inorganic } \\
\text { eutectic } \\
\text { mixture }\end{array}$ & 121 & 310 & 0.52 \\
\hline $\begin{array}{c}\mathrm{Capric} \mathrm{acid}(65.12 \%) \\
\text { and lauric acid } \\
(34.88 \%)\end{array}$ & $\begin{array}{c}\text { Organic } \\
\text { eutectic } \\
\text { mixture }\end{array}$ & 19.67 & 126 & 0.21 \\
\hline
\end{tabular}

The main advantage of phase change materials (PCM) is their high energy density, almost constant melting / freezing point and a significant reduction of storage dimensions compared to solutions without phase change $[3,7]$. Table 2 contains some examples of PCM.

The third method - the use of heat of chemical transformations takes advantage of the fact that heat is stored through endothermic processes, while the release of stored energy takes place through an exothermic process [7]. At present, costs and complex processes caused that this method has not found a wider application [7]. When selecting 
PCM for a particular application, one need to pay attention to a number of aspects as well as the parameters:

- Material.

Depending on the chemical composition of the phasechanging agent, the following are different $[4,5]$ :

- phase change temperature level,

- value of specific heat for the solid phase and for the liquid phase,

- value of enthalpy of phase change,

- thermal conductivity,

- thermal and chemical stability,

- etc.

In order to better illustrate the diversity of PCM in Fig.

1 , groups of materials are classified by temperature and enthalpy of the phase transition.

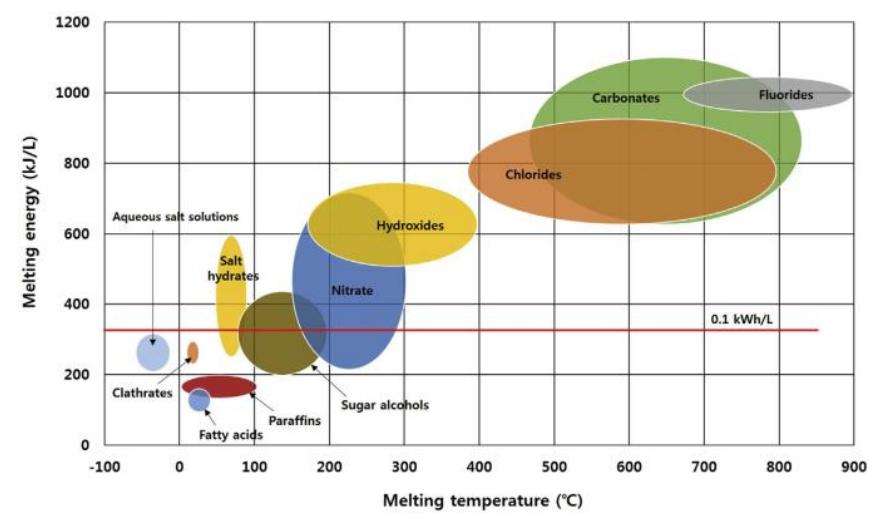

Fig. 1. Melting temp. and melting energy distribution of PCM [5]

- Working temperature.

In the case of a vehicle with a combustion engine, the system with heat storage can be built in such a way that thermal energy is taken from the cooling system of the drive unit (temperature to approx. $90^{\circ} \mathrm{C}$ ) or from the exhaust system (temperature up to $750^{\circ} \mathrm{C}$ ), which differs depending on the size of the engine, its speed and load [6]. PCM should be chosen so that its melting point is in the temperature range of the system [5].

- Design of heat storage

The design of the heat accumulator, exchangers as well as the materials used for its construction are of great importance for the system performance. The thermal capacity of the storage, the heat transfer value with the environment and with the variable phase material, the PCM phase change time, the charging time, etc. will depend on this. [3]. In the literature, comparisons of materials used to build the storage can be found, from which it follows that apart from the conditions in which the heat storage system will work, it is also important to choose the materials of the storage elements for the PCM that will be in it [3]. Corrosion of materials is a particularly important aspect [3].

- Safety

The material should be non-flammable and non-toxic [4, 5].

- Availability

Ideally, the material should not expensive to buy and its availability on the market not limited in any way $[4,5]$.
- Destination

The purpose of the system and the way it is fitted are the issues for the designer who has to meet the project assumptions in an optimal way.

In mobile applications, up to now two methods have been used - the use of specific heat of the substance and / or the use of phase-change energy of the substance. In the first case, the storage is in the form of an insulated vessel with a channel system with a certain amount of coolant, which stores heat during operation [1], in the second case the storage has a special construction that allows intensification of heat exchange between the circulating liquid and the PCM [1]. The first designs of PCM storages sometimes resulted in leaks, which caused PCM to mix with the working medium which could result in environmental contamination [1]. PCM technology is under intensive development, constantly improved structures of storages are becoming more and more reliable. What's more, currently used substances are less inconvenient for the natural environment.

A comparison of the heat storage charging process based on glycol and PCM (SAT) was also made (Fig. 2).

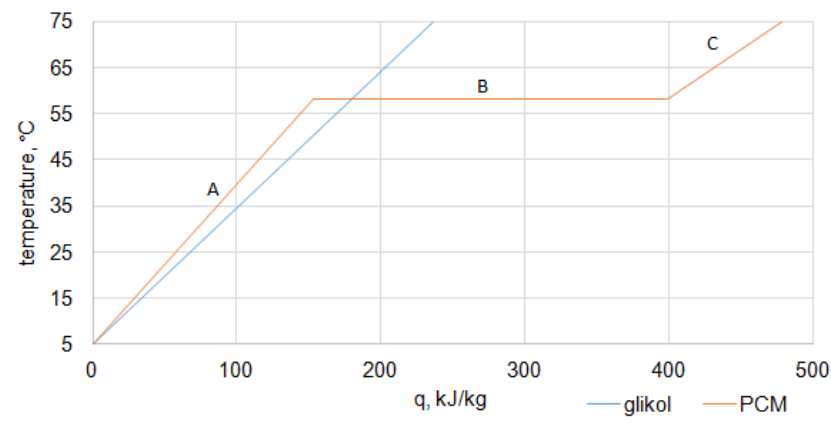

Fig. 2. Latent heat and sensible heat capacity (A - charging solid PCM; $\mathrm{B}$ - melting; $\mathrm{C}$ - charging liquid PCM)

From the Figure 2 it can be deduced that latent heat storage with SAT can store more energy in relation to sensible heat storage based on glycol (coolant).

\section{Test of latent heat storage}

\subsection{Heat storage with sodium acetate trihydrate (SAT)}

From a wide range of PCM materials, for the purpose of pre-tests was selected sodium acetate trihydrate $\left(\mathrm{CH}_{3} \mathrm{COONa} * 3 \mathrm{H}_{2} \mathrm{O}\right)$ was selected. Properties of this substance allow it to be used in military vehicles. The most important parameters of SAT can be recalled from the safety data sheet and literature:

- not flammable [9]

- not explosive [9]

- not classified as hazardous or harmful to health and the environment [9]

- may irritate the eyes and upper respiratory tract (in case of high dust concentration in the air) [9]

- density (in liquid phase) $1280 \mathrm{~kg} / \mathrm{m}^{3}[8]$

- thermal conductivity (in liquid) $0.4 \mathrm{~W} / \mathrm{m} \mathrm{K}$ [8]

- heat of fusion $264 \mathrm{~kJ} / \mathrm{kg}$ [8]

- melting point $58{ }^{\circ} \mathrm{C}[8]$. 
On the test stand equipped with a heat storage containing 60 litres of SAT (Fig. 3), the temperature and flow of heat exchange factors were measured, in cycles - charging and discharging of the storage. The storage has two copper exchangers immersed in PCM, and from the outside it is insulated with PU foam and a PVC jacket. Charging of the storage was carried out with the help of an electric heater. A stand is equipped with a control panel and a set of sensors so it is possible to enter and monitor system operation parameters.

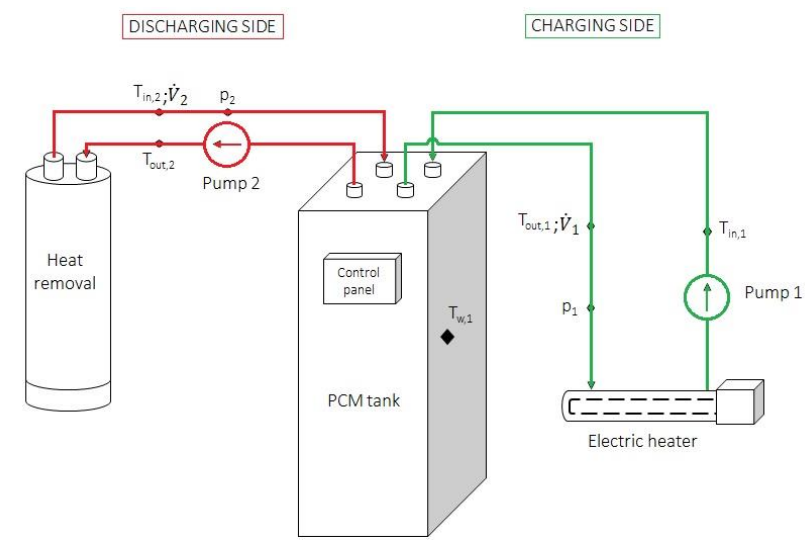

Fig. 3. Graphic scheme of the test stand at Institute of Thermal Technology, Silesian University of Technology, Gliwice

\subsection{Exploration of test stand}

Using an electric heater, the water was warmed up to $65^{\circ} \mathrm{C}$ and then a water stream $0.05 \mathrm{~kg} / \mathrm{s}$ was chargin PCM in storage tank. Charging PCM took 3 hours. Next step was a discharge of the storage, which also lasted 3 hours. The water stream on the discharging side was also set to 0.05 $\mathrm{kg} / \mathrm{s}$. After the discharge, the tank was passively cooling itself during 5 days.

Based on the obtained test results, the characteristics of the loading process and discharging were made (Fig. 4). The temperature fluctuation which can be observed in the tank wall temperature diagram is caused by the fact that in one room there were also tests carried out at another stand. When working with the storage, the wall temperature sensor may have been exposed to the ambient temperature.

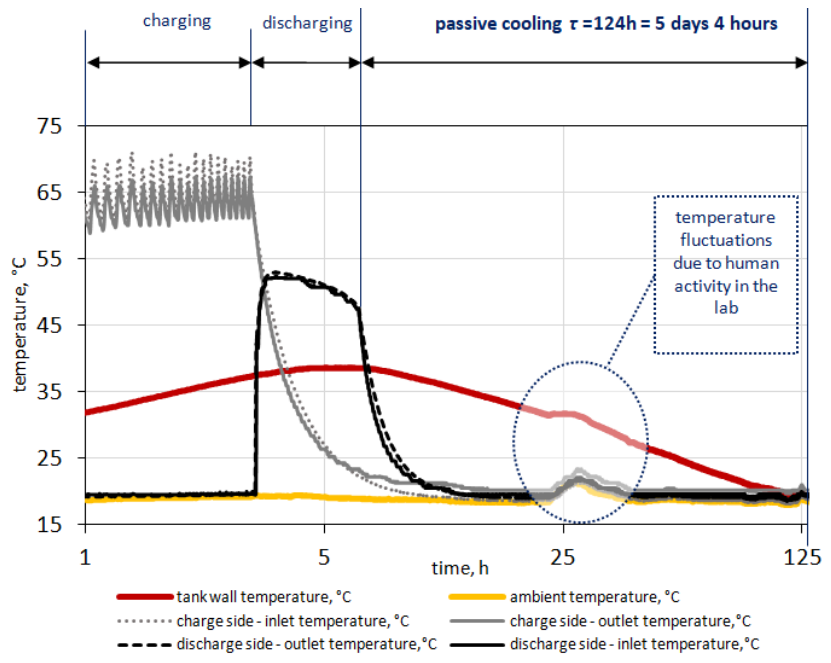

Fig. 4. Results of PCM tests

\section{Engine's warm up process}

\subsection{Description of process}

Analytical calculations of the process of self-heating of the CI engine under idle condition were carried out. The calculations were made for two variants with and without the use of physical enthalpy of the exhaust gases. In the first variant, a heat exchanger was used to partially recover the enthalpy of the exhaust gases, while in the second variant the exhaust gas was discharged directly to the surroundings. The exhaust gas warmed up the engine coolant, causing the internal combustion engine warm up faster. In order to determine the time needed to warm up the engine at ambient temperature, were used the results of experimental tests obtained earlier on the test stand. Scheme of test stand is presented in Fig. 5.

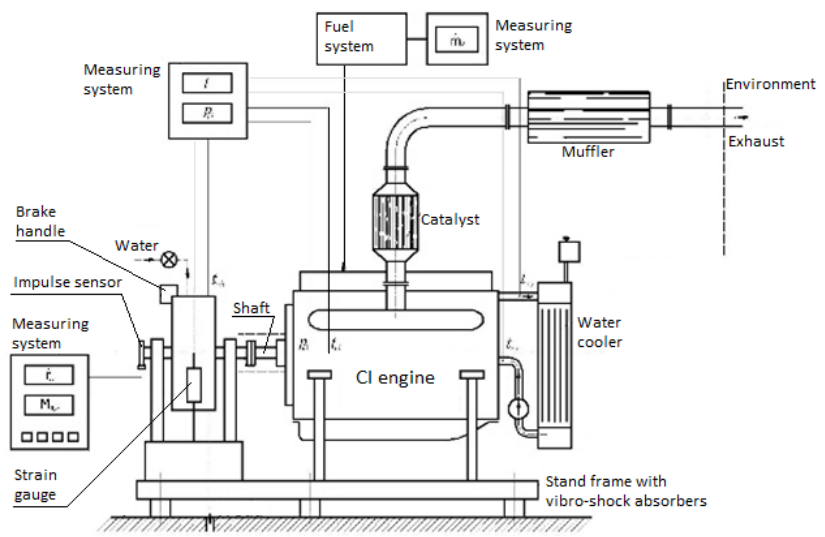

Fig. 5. Engine's test stand scheme [11]

Test stand is equipped with a 6-cylinder CI engine with a oxidizing catalyst. Engines parameters:

- volume: $6540 \mathrm{~cm}^{3}$,

- nominal power: $101.5 \mathrm{~kW}(2600 \mathrm{rpm})$,

- maximum torque: $423.65 \mathrm{Nm}$ (1600 rpm).

\subsection{Heat balance of the engine}

The analysis of the heat up process was made using the first law of thermodynamics. The balance of energy includes the chemical and physical enthalpy of substrates and products of the combustion process. Gases were treated as semi-perfect taking into account the influence of temperature on the change in the specific heat of individual components. The heat flow delivered to the environment was calculated based on the dependencies resulting from the equations describing the heat flow. The average value of the heat transfer coefficient (as a total, ie convective and radiation) from the external elements of the engine, to the environment was determined based on criterion equations for free convection. Figures 6 and 7 show schemes of the energy balance of an internal combustion engine, during the heating of the engine with (Fig. 7) and without (Fig. 6) heat coming from the enthalpy of exhaust gas.

Engine's heat balance equation:

$$
\left.\dot{\mathrm{I}}_{\mathrm{chp}}+\dot{\mathrm{I}}_{\mathrm{fp}}+\dot{\mathrm{I}}_{\mathrm{fa}}\right) \Delta \tau=\Delta \mathrm{U}_{\mathrm{e}}+\left(\dot{\mathrm{I}}_{\mathrm{che}}+\dot{\mathrm{I}}_{\mathrm{fe}}+\dot{\mathrm{Q}}_{\mathrm{ot}}\right) \Delta \tau
$$

Internal energy increase (engine $\&$ fluids):

$$
\Delta \mathrm{U}_{e}=\Delta \mathrm{U}_{g}+\Delta \mathrm{U}_{o}+\Delta \mathrm{U}_{s}
$$




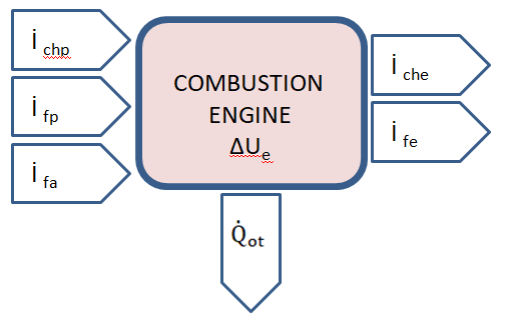

Fig. 6. Scheme of heat balance of the engine

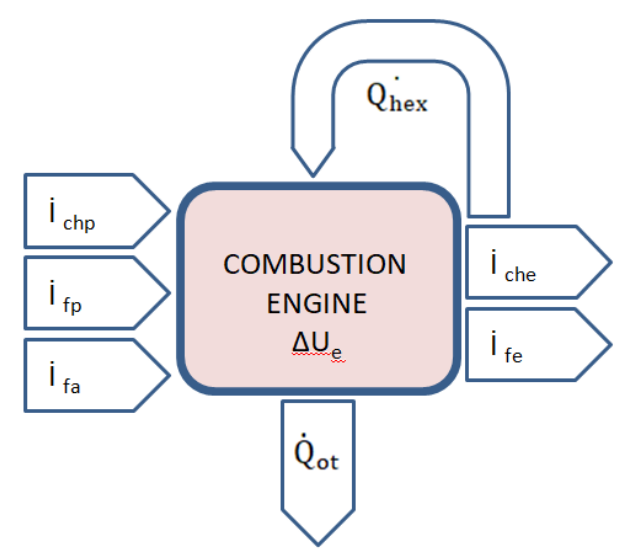

Fig. 7. Scheme of heat balance of the engine including heat coming from exhaust gas

Engine's heat balance equation:

$\left(\dot{\mathrm{I}}_{\mathrm{chp}}+\dot{\mathrm{I}}_{\mathrm{fp}}+\dot{\mathrm{I}}_{\mathrm{fa}}+\dot{\mathrm{Q}}_{\mathrm{hex}}\right) \Delta \tau=\Delta \mathrm{U}_{\mathrm{e}}+\left(\dot{\mathrm{I}}_{\mathrm{che}}+\dot{\mathrm{I}}_{\mathrm{fe}}+\dot{\mathrm{Q}}_{\mathrm{ot}}\right) \Delta \tau$

where: $\dot{\mathrm{I}}_{\mathrm{chp}}$ - chemical enthalpy of fuel [W], $\dot{\mathrm{I}}_{\mathrm{fp}}-$ physical enthalpy of fuel [W], $\dot{\mathrm{I}}_{\mathrm{fa}}$ - physical enthalpy of air [W], $\Delta \mathrm{U}_{\mathrm{e}}$ - internal energy increase $[\mathrm{J}], \dot{\mathrm{I}}_{\text {che }}$ - chemical enthalpy of exhaust [W], $\dot{\mathrm{I}}_{\mathrm{fe}}-$ physical enthalpy of exhaust [W], $\dot{\mathrm{Q}}_{\mathrm{ot}}-$ flux of heat loss [W], $\Delta \mathrm{U}_{\mathrm{g}}$ - energy of coolant $[\mathrm{J}], \Delta \mathrm{U}_{\mathrm{o}}-$ energy of oil $[\mathrm{J}], \Delta \mathrm{U}_{\mathrm{s}}-$ energy of steel $[\mathrm{J}], \dot{\mathrm{Q}}_{\mathrm{hex}}-$ heat flux from heat exchanger $[\mathrm{W}], \tau$ - time $[\mathrm{s}]$.

\subsection{Assumptions and test data}

As mentioned earlier, the analysis of the engine's heating process was carried out using the previously obtained experimental data. The data was obtained during tests of the engine operating in a steady state (quasi-stationary). Additionally, for the purposes of balance calculations:

- ambient temperature $-30^{\circ} \mathrm{C}$,

- end temperature I $+30^{\circ} \mathrm{C}$ - it was assumed that this is the temperature at which the vehicle can slowly move from the lowest gear positions,

- end temperature II $\quad+65^{\circ} \mathrm{C}$ - it was assumed that this is the temperature at which the vehicle can put maximum load on the drive system,

- variable engine speed: $600 \mathrm{rpm}$ and $1200 \mathrm{rpm}$,

- variable engine load: idle, $90 \mathrm{Nm}$ and $180 \mathrm{Nm}$.

The stream of consumed fuel was measured using a mass flow meter.

During the test, the composition of dry exhaust gases in the form of volume shares of the following substances was measured: $\mathrm{NO}_{\mathrm{x}}, \mathrm{CO}, \mathrm{CO}_{2}, \mathrm{HC} *$ (*equivalent to $\mathrm{C}_{6} \mathrm{H}_{14}[10]$ ).
In theoretical-experimental analysis, it was assumed that the average composition of the exhaust gases during the heating of the internal combustion engine will be similar to the data obtained in the stationary state during experimental investigations. In the future, it is planned to perform tests in a transient state taking into account the heating characteristics and the emission of harmful exhaust components.

\subsection{Results}

The measurements were made at engine speeds of 600 rpm and $1200 \mathrm{rpm}$ without engine load (idle run). Figure 8 presents the characteristics based on measurements and calculations of thermal balances.

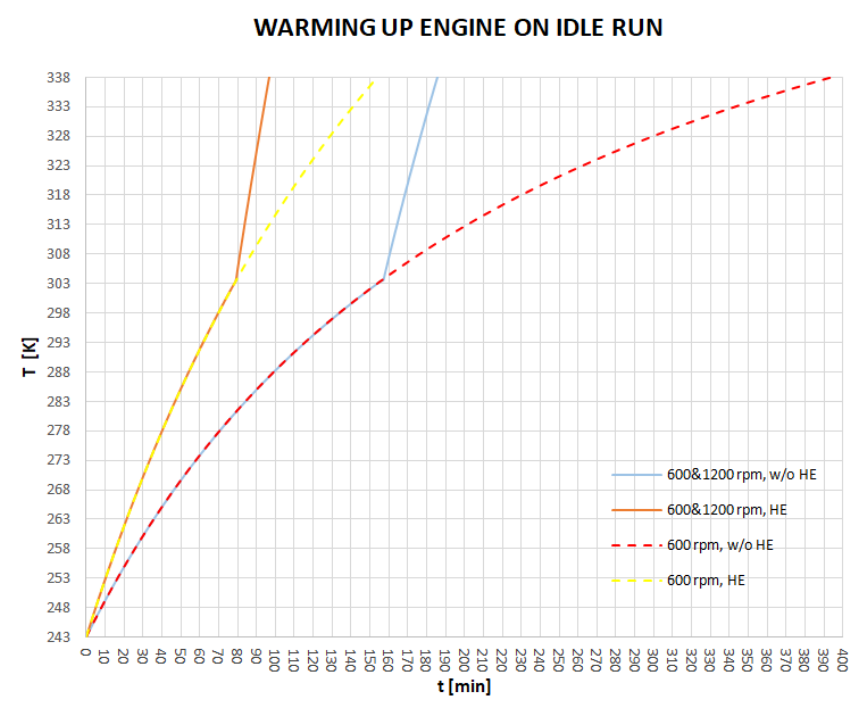

Fig. 8. Warming up diesel engine diagrams from $-30^{\circ} \mathrm{C}[243.15 \mathrm{~K}](\mathrm{HE}-$ with heat exchanger; w/o $\mathrm{HE}$ - without heat exchanger)

The engine warm-up from $-30^{\circ} \mathrm{C}$ at $600 \mathrm{rpm}$ under idle condition is shown using dashed lines. Red colour without additional heat source, and yellow with heat exchanger. In addition, after the engine reached $+30^{\circ} \mathrm{C}$, the effect of increasing the speed of rotation to $1200 \mathrm{rpm}$ on the heating time was checked (continuous lines of red and blue).

Figure 8 confirms that the effect of the additional heat source during engine start-up is significant. The engine warm up time, to $+30^{\circ} \mathrm{C}$ at $600 \mathrm{rpm}$ under idle condition has been reduced by 70 minutes and by $240 \mathrm{~min}$ in the case of heating up to $+65^{\circ} \mathrm{C}$. Increasing the engine speed to 1200 rpm after reaching the temperature of $+30^{\circ} \mathrm{C}$ caused that the heating times were further shortened. The results of theoretical calculations, showing the reduction of heating time (Fig. 8) may contain error due to the adopted, simplified heat exchange model.

\subsection{Comparison with research in a climatic chamber}

In order to verify the theoretical analysis presented above, the results from the test in a climatic chamber, a similar six-cylinder CI engine are shown. In Figure 9 the results of the temperature increase of engine parts and fluids measured during warming up process in climatic chamber are presented. At the beginning of the experiment the engine fluids has been preheated using combustion heater switched on for about 58 minutes. In the first part of the experiment the engine was operated under idle condition. 
After 40 minutes of engine work the functional test of vehicle started which lasted two hours [12].

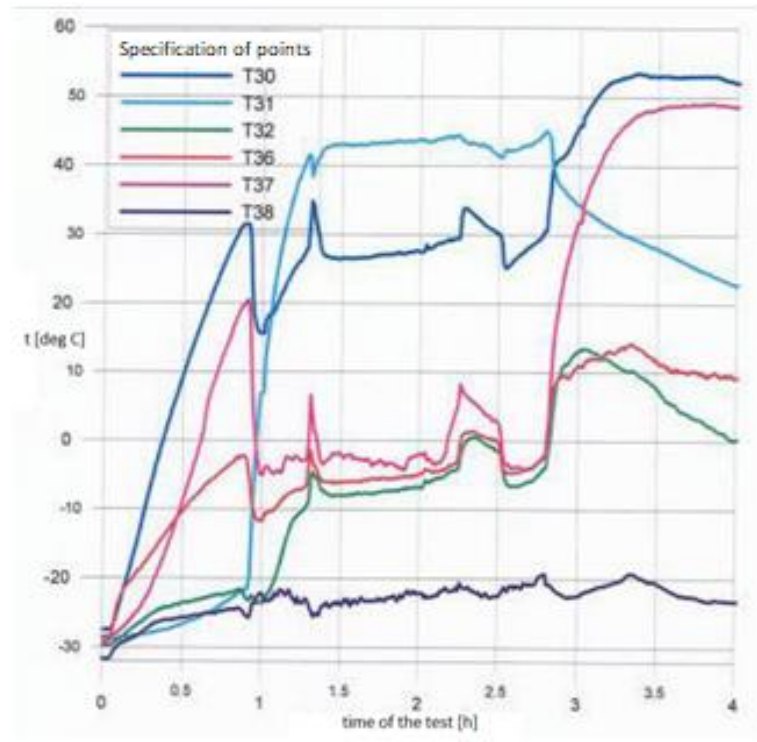

Fig. 9. The course of temperature change at selected points of the CI engine [12]

Description to Figure 9 [12]: T30 - temperature on the surface of the unit with the sensor to measure the temperature of the coolant, T31 --temperature of the engine oil in the oil sump, T36 - temperature on the surface of the engine block (sensor in the mounting - technological hole).

From the Figure 8 and 9 it can be seen that the difference in the results of the theoretical calculations and experimental test of similar engines is not significant. The reason of shorter time observed for experimental test is the use of combustion heater at the beginning of experiment.

\subsection{Analysis of exhaust components}

In addition to the analysis of the engine's heating time, the emission of harmful exhaust components was also analyzed (Fig. 10, 11, 12 and 13) based on the times shown in Fig. 8. It has been confirmed that the commissioning of a preheated engine significantly reduces the emission of harmful exhaust gas components.

Emission of harmful exhaust gas components was also carried out for the engine working under idle condition at $600 \mathrm{rpm}$ and $90 \mathrm{Nm}$ and $180 \mathrm{Nm}$ load at $1200 \mathrm{rpm}$. Concentration of exhaust components are shown in Fig. 14 and Fig. 15.

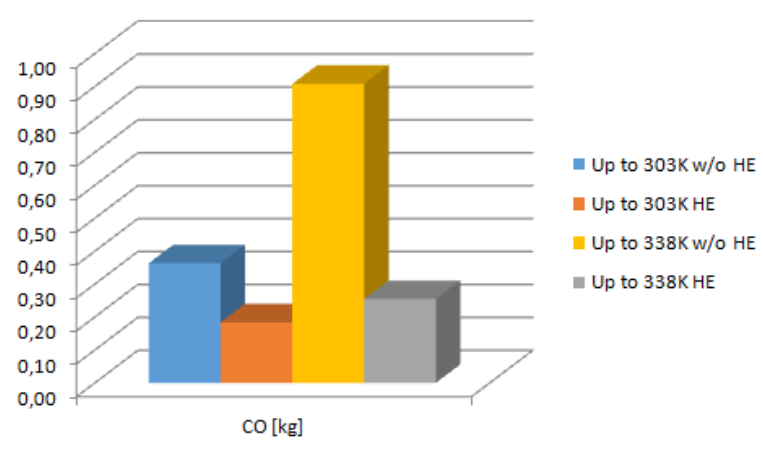

Fig. 10. Amount of $\mathrm{CO}$ after warming up (HE - with heat exchanger; w/o HE - without heat exchanger)

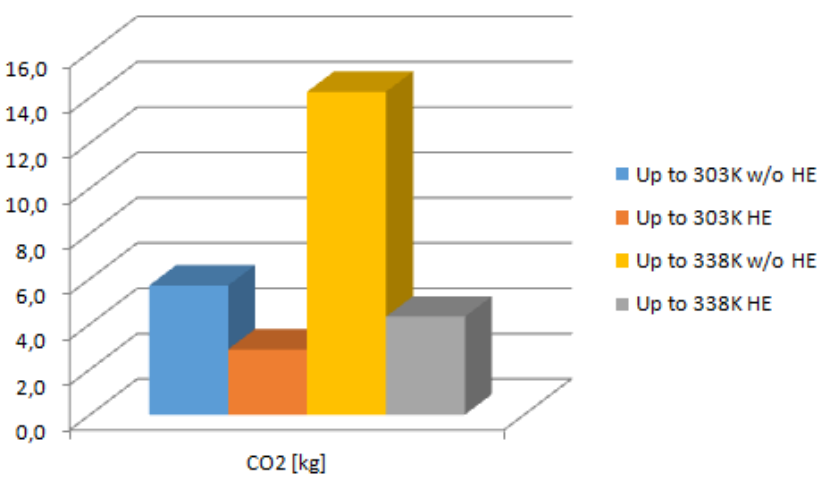

Fig. 11. Amount of $\mathrm{CO}_{2}$ after warming up ( $\mathrm{HE}$ - with heat exchanger; w/o HE - without heat exchanger)

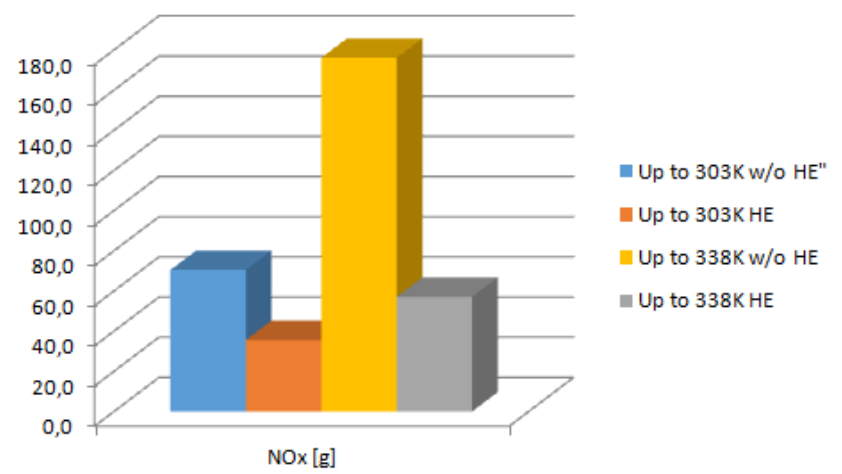

Fig. 12. Amount of $\mathrm{NO}_{\mathrm{x}}$ after warming up ( $\mathrm{HE}$ - with heat exchanger; w/o HE - without heat exchanger)

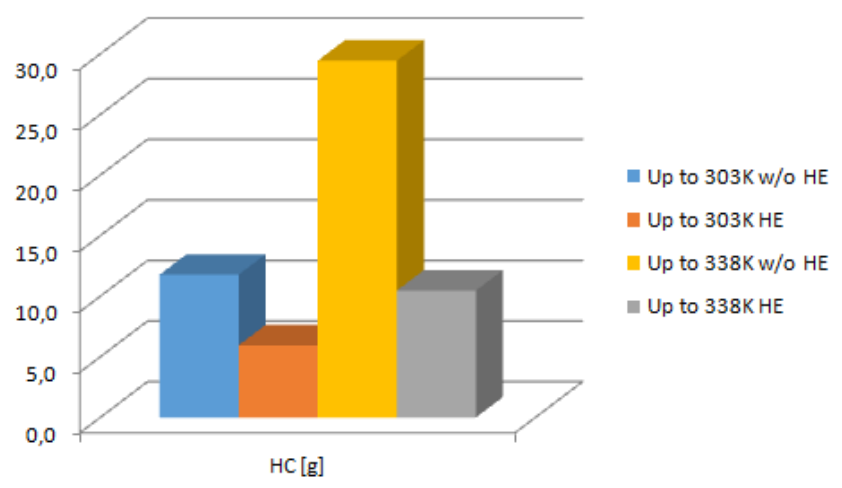

Fig. 13. Amount of $\mathrm{HC}$ after warming up (HE - with heat exchanger; w/o HE - without heat exchanger)

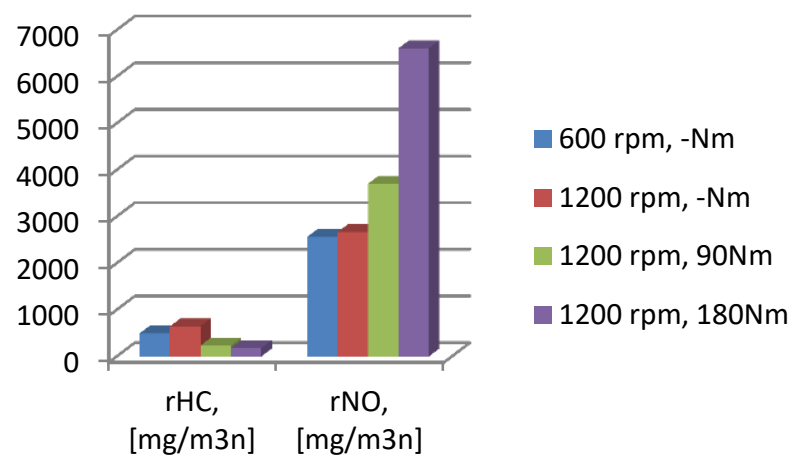

Fig. 14. Amount of $\mathrm{NO}_{\mathrm{x}}$ and $\mathrm{HC}$ concentration in exhaust gases 


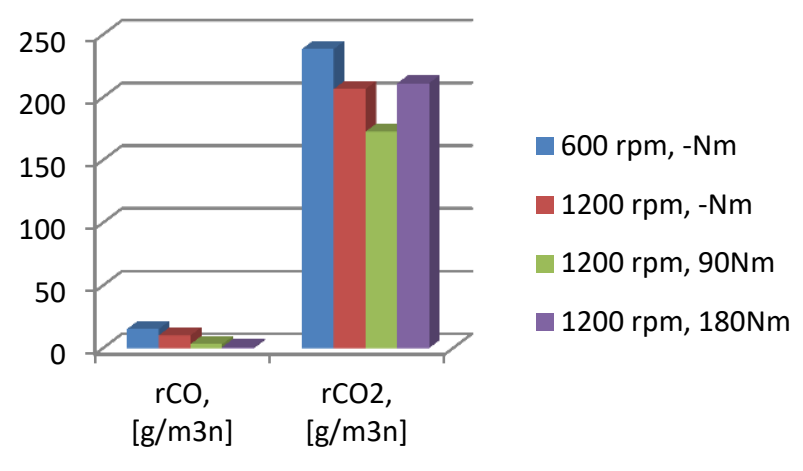

Fig. 15. Amount of $\mathrm{CO}$ and $\mathrm{CO}_{2}$ concentration in exhaust gases

The high $\mathrm{NO}_{\mathrm{x}}$ value in Fig. 14. is caused by the fact that the engine used only an oxidation catalyst.

\subsection{Theoretical analysis of the engine temperature}

depending on the amount of SAT in the heat storage

Based on the previously held assumptions and using the energy balance equation recorded for the system: combustion engine - PCM (SAT) storage, has been prepared characteristics (Fig. 16) which presents temperatures to which

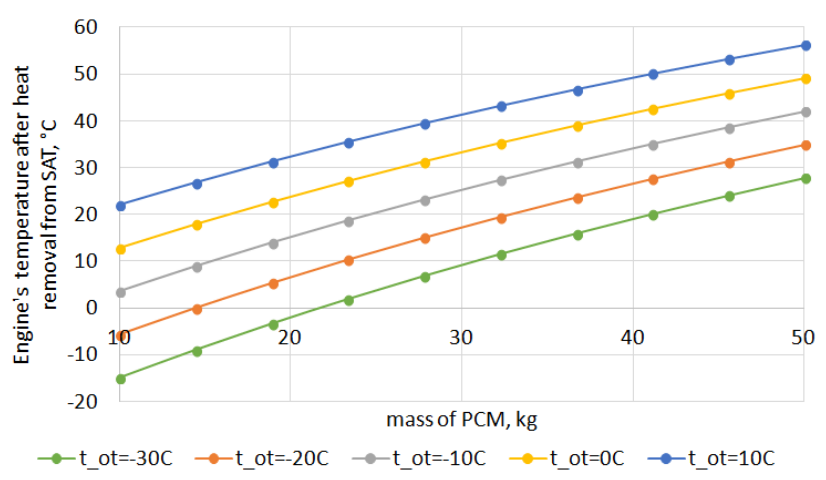

Fig. 16. Engine's temperature in relation to heat storage mass the given mass of PCM material (assumed 10, 20, 30, 40 and $50 \mathrm{~kg}$ ) can heat the motor body depending on the ambient temperature (t_ot). The range of adopted ambient temperature from $-30^{\circ} \mathrm{C}$ to $+10^{\circ} \mathrm{C}$.

\section{Conclusions}

The comparison of conventional heat storage system and the system with phase change material shows that the PCM system can achieve significantly less mass for the same heat capacity. The PCM accumulator, based on sodium acetate trihydrate has more than two times less mass comparing to the conventional accumulator based on glycol.

PCM (SAT) can be used in combat vehicles but due to the low melting point of SAT, it is not suitable for storing heat from the exhaust system. Therefore, reducing the thermal image of a vehicle in thermal imaging systems will not be effective.

The tests and analyses, carried out on the combustion engine and the heat accumulator have confirmed the validity of using heat storage systems in combat vehicles, which often have to be activated at low ambient temperatures in order to quickly and efficiently join to battlefield activities.

Analytical calculations of the process of self-heating of the CI engine confirms, that the additional heat source during engine start-up, significant reduce engine's heating time and emission of toxic exhaust components to the environment. To confirm the obtained results, it is necessary to perform experimental tests on the vehicle during natural conditions.

The design of the heat accumulator should be adapted to the vehicle. A well-chosen heat storage's capacity will allow to warm up the engine parts and fluids to the desired temperature within a certain time.

Selection of PCM and the design of the heat storage system for the combat vehicle, requires further $\mathrm{R} \& \mathrm{D}$ works.

\section{Nomenclature}

PCM phase change material

SAT sodium acetate trihydrate

CI compression ignition

\section{Bibliography}

[1] BRZEŻAŃSKI, M., MĘŻYK, P. Starters of combustion engines in military vehicles. Combustion Engines. 2015, 162(3).

[2] BRZEŻAŃSKI, M., MEŻZYK, P. Heat balance of the military vehicle. Combustion Engines. 2017, 170(3). DOI: 10.19206/CE-2017-322

[3] DINKER, A., AGARWAL, M., AGARWAL, G.D. Heat storage materials, geometry and applications: a review. Journal of the Energy Institute. 2017, 90, 1-11.

[4] ALVA, G., LIN, Y., FANG, G. An overview of thermal energy storage systems. Energy. 2018, 144, 341-378.

[5] PARK, S., WOO, S., SHON, J., LEE, K. Experimental study on heat storage system using phase-change material in a diesel engine. Energy. 2017, 119, 1108-1118.

[6] BARI, S., HOSSAIN, S.N. Waste heat recovery from a diesel engine using shell and tube heat exchanger. Applied Thermal Engineering. 2013, 61, 355-363.

[7] http://www.cire.pl/item,139841,2,0,0,0,0,0,magazynowanieciepla---rodzaje-magazynow.html, retrieved 04.2019.

[8] ENGLMAIR, G., MOSER, Ch., FURBO, S. et al. Design and functionality of a segmentem heat-storage prototype utilizing stable supercooling of sodium acetate trihydrate in a solar heating system. Applied Energy. 2018, 221, 522534.

[9] Safety data sheet of sodium acetate trihydrate E-262(i)/Karta charakterystyki substancji octan sodu trójwodny E-262(i), SA Chemicals, date of prep. 04.11.2014, date of update 04.06.2015.

[10] PRZYBYŁA, G. Studium stosowania biopaliw gazowych do zasilania silników spalinowych. Wydawnictwo Politechniki Śląkiej. Gliwice 2015.

[11] PRZYBYŁA, G. Wpływ parametrów obciążenia silnika spalinowego na przebieg generacji ciepła oraz efektywność 
konwersji energii w układzie. Rozprawa doktorska. Gliwice 2007.

[12] Raport z badań klimatycznych prototypu mostowego pojazdu transportowego [...] w warunkach obniżonych tempera-

Przemysław Mężyk, MEng. - Research and Development Centre for Mechanical Appliances OBRUM

Ltd., Gliwice.

Institute of Thermal Technology, Silesian University of Technology.

e-mail:przemyslaw.mezyk@obrum.gliwice.pl tur do $-30^{\circ} \mathrm{C} \pm 2,5^{\circ} \mathrm{C}$ oraz podwyższonych temperatur do $+55^{\circ} \mathrm{C} \pm 2,5^{\circ} \mathrm{C}$. Kraków 2008 . Unpublished document.

Grzegorz Przybyła, DSc., DEng. - Institute of Thermal Technology, Silesian University of Technology.

e-mail: grzegorz.przybyla@polsl.pl

Karolina Petela, MEng. - Institute of Thermal Technology, Silesian University of Technology.

e-mail: karolina.petela@polsl.pl 